\title{
OPTIMALIZACE SOUVRSTVÍ PRO ZELENÉ PARKOVIŠTĚ PŘI VYUŽITÍ ROŠTŮ AS-TTE
}

\author{
OPTIMIZATION OF THE CONSTRUCTION LAYERS OF GREEN \\ PARKING LOT WHEN USING AS-TTE GRASSING BLOCKS
}

\author{
Michal Novotný, ${ }^{* 1}$, Tomáš Chorazy² \\ "novotny.m3@fce.vutbr.cz \\ ${ }^{1}$ Vysoké učení technické v Brně: Fakulta stavební, Ústav vodního hospodářství obcí, Veveří 331/95, 60200 Brno \\ ${ }^{2}$ Vysoké učení technické v Brně, Fakulta stavební, Centrum AdMaS, Purkyňova 651/139, 61200 Brno
}

\begin{abstract}
Abstrakt
Současným trendem při odvodnění vozovek pozemních komunikací je soustředění deštové vody do podloží vozovek tak, aby se neztrácela v kanalizačních systémech, ale volně se saturovala do podloží. Cílem tohoto výzkumu je optimalizovat konstrukční vrstvy zelených parkovišt' při použití zasakovacích roštů AS-TTE.

Během návrhu konstrukčních vrstev budou jednotlivé nové typy materiálů včetně podkladních vrstev optimalizovány tak, aby umožnily maximální vsakování vody do podloží a zároveň byly dodrženy požadavky na únosnost konstrukčních vrstev dle ČSN 72 1006. Budou provedeny laboratorní zkoušky zaměřené na základní fyzikálně-mechanické vlastnosti, propustnost vody a adsorpci ropných látek.
\end{abstract}

\section{Klíčová slova}

Modrozelená infrastruktura, zelené parkoviště, biouhel, adsorpce ropných látek.

\begin{abstract}
The current way in drainage of roads is the concentration of rainwater in the subsoil of roads, so that rainwater does not drain into the sewer system, but freely infiltrates into the subsoil. The aim of this research is to optimize the structural layers of green parking lots with AS-TTE grassing blocks. During the design of structural layers and new types of materials, will be optimized to allow maximum water infiltration into the subsoil and at the same time keep the requirements for load-bearing capacity of structural layers according to ČSN 721006 . Laboratory tests will be performed focusing on basic physical and mechanical properties, water permeability and adsorption of oil drips.
\end{abstract}

\section{Key words}

Blue-green infrastructure, green parking lot, biochar, oil adsorption.

\section{1 ÚVOD}

Srážková voda se dnes z většiny zastavěných nebo jinak povrchově uzavřených oblastí nedostane přirozenou cestou zpět do prírodního koloběhu vody. To může zapříčinit pozvolné, dlouhodobé změny půdní struktury a vodních režimů, které vedou $\mathrm{k}$ zmenšení přirozené místní obnovy spodních vod a mají dopad na chemické a biologické poměry nad terénem i pod ním. Navíc neškodné odvedení povrchových odtoků, zejména těch extrémních za silných srážkových událostí, si vyžaduje značné technické a finanční výdaje při projektování, výstavbě a provozu stokových sítí a čistíren odpadních vod. Přes veškerá technická opatření se však některé extrémní odtoky dostávají do povrchových vod. To může vést k povodňovým stavům, či nárůstu znečištění $\mathrm{v}$ malých tocích na povodích s výrazným podílem ploch sídel. Přihlédneme-li k možnému znečištění, které odvodňované plochy mohou uvolnit, je pak včlenění srážkových vod zpět do přirozeného koloběhu vody co nejblíže místu jejich dopadu cílem ekologicky, vodohospodářsky a technicky smysluplným, a může být výhodné i z hlediska národohospodářského. Proto je třeba, při zohlednění místních podmínek, sledovat v první řadě redukci povrchového odtoku a jeho lokální vsakování, a teprve v druhé řadě se uchýlit k zavedení vod do stokové sítě [1]. 
Půda zajišt’uje mnoho základních ekologických funkcí, především sehrává klíčovou roli v produkci potravin a produkci biologických obnovitelných zdrojů (dřevo), poskytuje místo pro biologickou rozmanitost v půdě i na jejím povrchu, filtruje a zpomaluje proud vody a zároveň z ní odstraňuje znečišt’ující látky, pomáhá snižovat četnost a riziko záplav a sucha, pomáhá regulovat mikroklima zejména v městském prostředí [2]. Zakrývání půdy (soil sealing) je definováno jako zakrytí půdy nepropustnými materiály (beton, asfalt), čímž půda ztrácí své přirozené vlastnosti a není nadále schopna plnit své přírodní funkce. Zakrývání půdy je negativní proces při přirozené urbanizaci a rozšiřování měst. Ignorování tohoto problému však může vést k výrazným ztrátám kvalitní zemědělské půdy, k urychlení klimatických změn, ke snížení biodiverzity v daném území [3], [4].

\section{POPIS SOUČASNÉHO STAVU}

Jeden z významných prvků hospodaření s deštovou vodou jsou i zelené propustné povrchy. Jejich realizace však nebyla po praktické stránce obvykle dobře zvládnuta - betonové prvky nadměrně zahřívají a vysušují povrch a potřebné podkladní vrstvy neumožňovaly dobrou komunikaci vody, a tedy zásobování zeleně. Zpevněné propustné povrchy s AS-TTE rošty se snaží pojmout řešení komplexně a tyto nedostatky odstranit [5]. Předmětem výzkumu je vyvinout optimální souvrství pro zelené parkoviště v kombinaci se zasakovacími rošty AS-TTE.

Během návrhu konstrukčních vrstev budou jednotlivé nové typy materiálů včetně podkladních vrstev optimalizovány tak, aby umožnily maximální vsakování vody do podloží a zároveň byly dodrženy požadavky na únosnost konstrukčních vrstev dle ČSN 72 1006. Budou provedeny laboratorní zkoušky zaměřené na základní fyzikálně-mechanické vlastnosti, propustnost vody a adsorpci ropných látek. Zvýšení efektivity představuje optimální propojení funkčních podmínek dopravní infrastruktury (zejména únosnosti a trvanlivosti) s potřebami tzv. modrozelené infrastruktury urbanizovaného území (budování zelených ploch pro zlepšení mikroklimatických podmínek a saturace srážkových vod do podzemí).

Jeden z inovativních prvků při budování experimentálního polygonu je využití tzv. biouhlu/biocharu do konstrukční vrstvy parkovacích stání. Vychází to z aktuálního trendu inovativních řešení v rámci modrozelené infrastruktury urbanizovaného území [6]. Inovované konstrukční podkladní vrstvy s obsahem biocharu umožní odvodnění navrženého parkoviště v kombinaci s nosnými rošty z recyklovaných materiálů, které zajistí dostatečnou únosnost a mezerami zajišt’ující dobré vsakování do podloží.

Na základě výzkumu byl do určité míry prokázán pozitivní vliv biocharu při využívání k čištění deštových vod. Provedené studie ukazují, že biochar je účinný při čištění srážkových vod z př́ívalových dešt’ů [7]. Biochar je schopný odstraňovat různé znečišt'ující látky, jako např. těžké kovy, polokovy, pesticidy a další. Odstraňování znečištujících látek je závislé na vlastnostech znečišt'ující látky, vlastnostech biocharu a podmínkách čištění [8].

Další inspiraci lze nalézt u řady praktických aplikací, které se v rámci Smart City iniciativ apod. realizují v řadě evropských i mimoevropských měst. Například Stockholm Biochar Project [9], kdy zde od roku 2017 běží průmyslová linka na výrobu biocharu z městského organického odpadu se základním cílem sekvestrace uhlíku do půdy a řady místních projektů regenerace zelených ploch, výsadbě stromů, zelených parkovišt’ apod.

\section{Zkušební zelené parkoviště}

Ve výzkumném centru AdMaS byly vybudovány celkem tři testovací parkovací plochy pro provedení zkoušek únosnosti konstrukčních vrstev a provedení simulace s vyhodnocením znečištění zeleného parkoviště úkapy ropných produktů.

Parkoviště navazuje na stávající asfaltovou příjezdovou komunikaci, a kromě testovacích parkovacích ploch ji tvoří „referenčni““ vydlážděný chodník (standardně vybudovaný ze zámkové dlažby) a upravená štěrková plocha. Samotné experimentální parkoviště je sestaveno ze tří parkovacích stání. Parkovací stání A je celé vyplněno dlažebními kostkami, tedy jakoby konvenčním způsobem ovšem stále se jedná o propustný povrch bez sorpčních podkladních vrstev. Parkovací stání B a C jsou z poloviny vyplněna dlažebními kostkami a z poloviny oseté trávou = zelené parkovací stání. Parkovací stání a pojížděné zpevněné plochy jsou lemovány betonovým chodníkovým obrubníkem do betonového lože s boční betonovou opěrou. Šírka parkovacího stání je 2,5 m a délka je 5,3 m. Podélný sklon parkovacích stání je 2,5\%. Níže v textu jsou charakterizovány konstrukční vrstvy jednotlivých parkovacích stání. Dokončené parkoviště s označením jednotlivých parkovacích stání je zobrazeno na Obr. 1 [6].

Základové podloží parkoviště je zhutněná zemní pláň skládající se především ze zeminy CL-ML (nízko plastické jíly až hlíny). Tato zhutněná zemní pláň byla dorovnána vrstvou štěrkodrtě, frakce 0-32 mm, tloušt'ky $50 \mathrm{~mm}$. Svrchní vrstva všech parkovacích polí je složená ze zasakovacích roštů AS-TTE, která je v prrípadě parkovací plochy A a B podsypána substrátem Soil-P vrstvy $50 \mathrm{~mm}$. Rošty parkovacího pole C jsou uloženy př́mo na hlavní konstrukční vrstvě z drceného kameniva frakce $0-32 \mathrm{~mm}$ a tloušt'ky vrstvy $200 \mathrm{~mm}$. Hlavní konstrukční vrstvu, tloušt'ky $200 \mathrm{~mm}$, parkovacího pole B tvoří směs ornice, biouhlu a štěrku frakce 0-32 mm. Konstrukční vrstva parkovacího stání A o mocnosti 200 mm je ze směsi ornice a štěrku frakce 0-32 mm. 


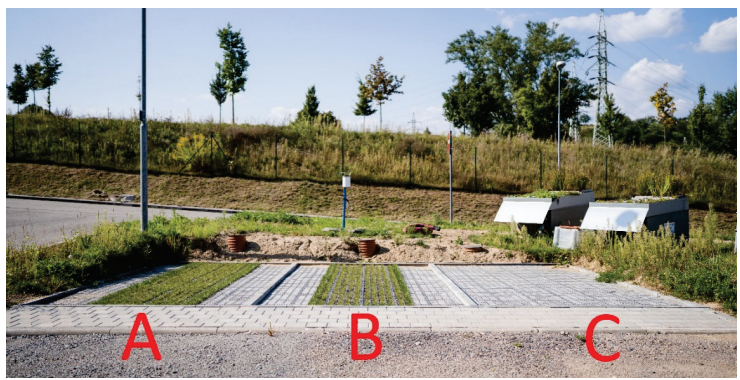

Obr. 1 Zkušební zelené parkoviště v centru AdMaS.

\section{Zasakovací rošty AS-TTE}

Zasakovací rošty jsou tvořeny nosnou částí (roštem), která zajišt’uje dostatečnou únosnost a mezerami zajišt'ujícími dobré vsakování do podloží. Jedná se o stavebnicové systémy vyráběné ze $100 \%$ recyklovaného plastu. Mezery jsou vyplněny dobře propustným materiálem, jako je štěrk, dlažební kostka nebo propustnou zeminou se zatravněním. Výhodou je jednoduchost, nízké pořizovací náklady při zajištění dostatečné únosnosti a stálosti povrchu, nenáročná údržba.

Rošty jsou spojované pomocí zámkového systému, a to zaručuje optimální rozložení tlaku. Ve srovnání s obvyklou skladbou vrstev dojde k většímu rozložení zatížení na plochu, což umožní uspořit 50-100 \% nákladů na podkladní vrstvy. Ve vertikální ose polohovou stálost zajišt’uje především správně zvolená skladba. U systémového řešení AS-TTE line, vypomáhají roznášení zátěžové síly do plochy zámky na každém roštu. Díky tomu je požadována, někdy i méně než poloviční, podkladní vrstva což zaručuje značnou úsporu investic na čase a materiálu. A to nejen na materiálu podkladním, ale také na materiálu (zeminy), která se musí ze stavby odvést [5].

\section{Biochar jako pomocná složka v substrátu}

Biochar je porézní uhlíkatá tuhá látka vyrobená termochemickou konverzí organických materiálů v atmosfére zbavené kyslíku, mající fyzikálně-chemické vlastnosti vhodné pro bezpečné a dlouhodobé ukládání uhlíku v životním prostředí [10].

Vzhledem ke svým vlastnostem a stabilní organické formě, která mimo jiné sekvestruje uhlík a zamezuje tak jeho zpětnému uvolňování do atmosféry, může být biochar atraktivním materiálem v oblastech zemědělství, lesnictví, ale i v městských oblastech při realizaci zelených střech, fasád a propustných ploch [6]. Svojí strukturou se liší od uhlí a má obsah živin (mimo dusíku) stejný jako původní biomasa. Tyto živiny se z biocharu uvolňují zvolna postupně a uhlík je v něm vázaný po staletí až tisíciletí. Svými adsorpčními vlastnostmi je tento materiál podobný aktivnímu uhlí (specifický povrch sušiny má být $>150 \mathrm{~m}^{2} \cdot \mathrm{g}^{-1}$ ), takže sorbuje pachy, zvyšuje kationtovou výměnnou kapacitu půdy, sorbuje nebezpečné látky do méně vyluhovatelné formy a zlepšuje vodní režim půdy, protože dokáže zadržovat až šestinásobek svojí hmotnosti. Neopomenutelnou předností je rovněž výše uvedená, však nepř́iliš detailně komentovaná schopnost vázat na sebe živiny, které jsou následně postupně pozvolna uvolňovány do půdního prostředí, odkud jsou rostlinami čerpány [11]. Existuje celé spektrum možného využití tohoto produkovaného uhlíkatého zbytku.

\section{METODIKA}

\section{Statické zatěžovací zkoušky}

Dlážděné konstrukce vozovek můžeme rozdělit především podle dopravního zatížení, které se bude po dlážděné vozovce pohybovat. $\mathrm{V}$ tomto případě můžeme zásadní rozdíl konstrukce vidět v použití nestmelené podkladní vrstvy pro dlážděné kryty s vyloučením motoristické dopravy nebo s použitím jen pro osobní vozidla. V prŕípadě zatížení těžkými nákladními vozidly (nad 3,5 t) je vhodné použití podkladních vrstev stmelených hydraulickými pojivy nebo použití několika nestmelených vrstev nad sebou. Z tohoto předpokladu se vyšlo i v případě návrhu zkušebního úseku parkoviště pro osobní vozy [6].

Zpevněné parkovací plochy jsou navrženy tak, aby byly zajištěny potřebné hodnoty zhutnění pláně a konstrukčních vrstev jednotlivých parkovacích ploch. Očekávaná třída dopravního zatížení je VI (TNVk < 15). 
Podmínkou provádění stavebních prací na zpevněných plochách je dodržení minimální hodnoty modulu přetvárnosti podloží zeminy $\mathrm{E}_{\text {def }, 2}=45 \mathrm{MPa}$ pro jemnozrnné zeminy. Modul přetvárnosti je nutno ověřit statickou zatěžovací zkouškou podle ČSN 72 1006. Zemní pláně jsou zhutněny na min. modul přetvárnosti $E_{\text {def, } 2} / E_{\text {def, } 1}$ $<2,5$. Minimální hodnota modulu přetvárnosti podsypné vrstvy ŠDa $200 \mathrm{~mm}$ je $\mathrm{E}_{\text {def, } 2}=80 \mathrm{MPa}$ (ČSN 72 1006). Podkladní nosné vrstvy jsou zhutněny na min. modul přetvárnosti $\mathrm{E}_{\mathrm{def}, 2} / \mathrm{E}_{\mathrm{def}, 1}<2,5[6]$.

\section{Adsorpce ropných látek}

Cílem simulace je vyhodnotit schopnosti filtračního materiálu v tělese experimentálního parkoviště z AS-TTE roštů adsorbovat olejové úkapy, které se při srážkách dostávají z parkovišt' do kanalizací, podloží, podzemní vody apod. Testování proběhlo v laboratoři městského inženýrství v centru AdMaS. Filtrační materiál odpovídá skladbě experimentálních polygonů zeleného parkoviště vybudovaného na venkovní ploše centra AdMaS.

Testování proběhlo v rámci standardizovaného modulu s půdorysnými rozměry $28 \times 28 \mathrm{~cm}$ o výšce $50 \mathrm{~cm}$, viz Obr. 2 (vpravo). Tři stěny modulu jsou vyrobeny z $1 \mathrm{~cm}$ silného plastu, čtvrtá stěna je vyrobena $\mathrm{z}$ plexiskla. Skladba vrstev odpovídá složení a mocnosti konstrukci experimentálního parkoviště. Hutnění podkladních nosných vrstev je provedeno 5 údery betonovým kvádrem o váze 7,73 kg. Betonový kvádr je samovolně spuštěn na dřevěnou desku ze vzdálenosti $5 \mathrm{~cm}$, vrstvy jsou hutněny po $5 \mathrm{~cm}$. Hutnění výplňových vrstev je provedeno 3 údery identickým betonovým kvádrem z výšky $5 \mathrm{~cm}$. Připravený testovaný modul odpovídající jednotlivým experimentálním polím je nasazen na standardizovanou testovací stolici a do středu půdorysné plochy je nadávkována zkušební tekutina (motorový olej Shell Helix HX5 15W-40), viz Obr.2 (vlevo). Následně je modul zaklopen a připojenými hadičkami je z dávkovacího čerpadla spuštěna simulace srážkové události [6].

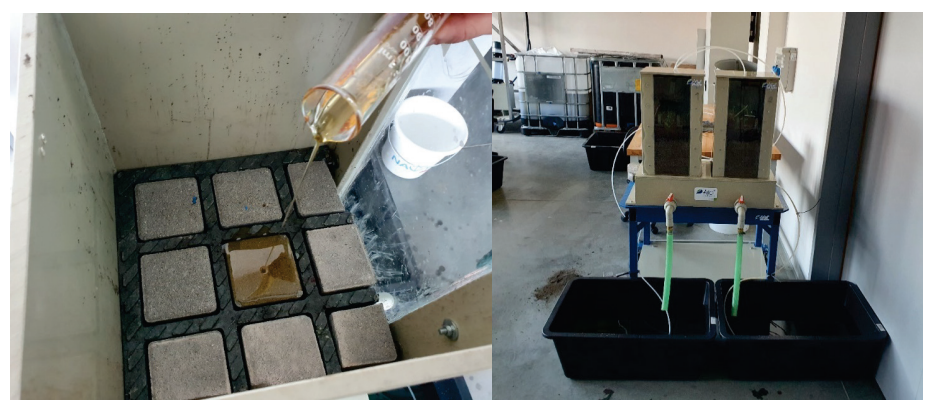

Obr. 2 Ukázka dávkování oleje (vlevo) a osazené testovací moduly (vpravo).

V rámci dalšího testování budou také laboratorně otestovány adsorbční schopnosti vázat olejové úkapy různých geotextilií. Přehled použitých geotextilií je na Obr. 3. Budou porovnány adsorbční geotextilie dostupné v rámci ČR, ale také speciální adsorbční geotextilie vyráběná ve Francii. Porovnání bude probíhat vzhledem k obyčejné netkané geotextilii o hmotnosti $300 \mathrm{~g} / \mathrm{m}^{2}$.

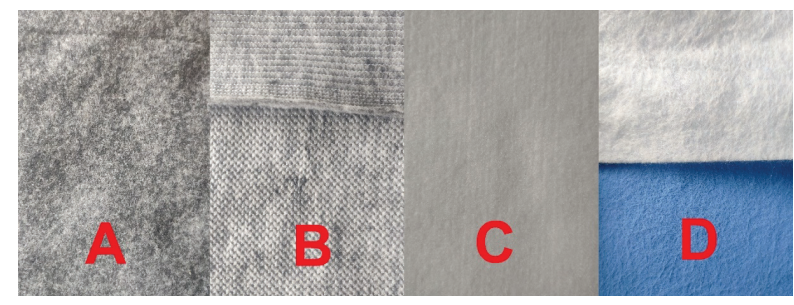

Obr. 3 Ukázka testovaných geotextilií (A-běžná netkaná geotextilie o hmotnosti $300 \mathrm{~g} / \mathrm{m}^{2}$; B-adsorbční geotextilie LAPOLTEX A300; C-adsorbční geotextilie GEO SORP STAR X400; D-adsorbční geotextilie TenCate GeoClean).

\section{VÝSLEDKY}

Cílem experimentu bylo prokázat únosnost konstrukčních vrstev při použití netradičních směsí alespoň na úroveň únosnosti pozemních komunikací. Statické zatěžovací zkoušky nezhutněné a zhutněné pláně proběhly na zařízení 
ECM-Static v. č. $245 \mathrm{~s}$ průměrem desky $300 \mathrm{~mm}$ a převodovým poměrem $1: 2$. Uvedené tabulky představují naměřená data z průběhu statických zkoušek [6].

Tab. 1 Statické zatěžovací zkoušky zhutněné pláně [6].

\begin{tabular}{|c|c|c|c|}
\hline & $\begin{array}{c}\text { Modul přetvárnosti } \mathbf{E}_{\text {def, } 1} \\
{[\mathrm{MPa}]}\end{array}$ & $\begin{array}{c}\text { Modul přetvárnosti } \mathbf{E}_{\mathrm{def}, 2} \\
{[\mathrm{MPa}]}\end{array}$ & 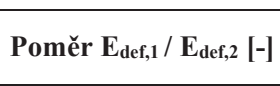 \\
\hline 1. měření & 11,1 & 42,0 & 3,8 \\
\hline 2. měření & 27,5 & 58,0 & 2,1 \\
\hline
\end{tabular}

Dle výsledků uvedených v Tab. 1 se při prvním měření nepodařilo prokázat únosnost zhutněné pláně. Bylo doporučeno dorovnat pláň vrstvou $50 \mathrm{~mm}$ štěrku frakce $0-32 \mathrm{~mm}$ a zhutnit vibrační deskou od nejnižšího místa v příčných pásech. Při druhém měření již zhutněná pláň splňuje požadavky dle metodiky.

Tab. 2 Statické zatěžovací zkoušky podkladních vrstev [6].

\begin{tabular}{|c|c|c|c|c|}
\hline & Parkovací pole & $\begin{array}{c}\text { Modul přetvárnosti } \\
\text { Edef,1 }_{\text {[MPa] }}\end{array}$ & $\begin{array}{c}\text { Modul přetvárnosti } \\
\text { Edef,2 }_{\text {[MPa }]}\end{array}$ & Poměr $\mathbf{E}_{\text {def, }, 1} / \mathbf{E}_{\text {def, }, 2}[-]$ \\
\hline \multirow{3}{*}{$\begin{array}{c}1 . \\
\text { měření }\end{array}$} & Pole A & 24,7 & 79,0 & 3,2 \\
\hline & Pole B & 6,1 & 46,0 & 7,6 \\
\hline & Pole C & - & 39,0 & nestanovitelný \\
\hline \multirow{3}{*}{$\begin{array}{c}2 . \\
\text { měření }\end{array}$} & Pole A & 50,8 & 123,6 & 2,4 \\
\hline & Pole B & 73,3 & 111,9 & 1,5 \\
\hline & Pole C & 79,5 & 97,2 & 1,2 \\
\hline
\end{tabular}

Dle výsledků uvedených v Tab. 2 se při prvním měření u všech třech polí nedokázalo prokázat únosnost podkladních vrstev. Bylo doporučeno pokračovat v hutnění konstrukčních vrstev. Hutnění probíhalo vibrační deskou od nejnižšího místa v příčných pásech. Následná druhá zatěžovací zkouška prokázala dostatečnou únosnost všech parkovacích polí dle uvedené metodiky.

Vyhodnocení laboratorního experimentu na adsorbci olejových úkapů je uvedeno v Tab. 3. Dle testovaných souvrství a použitých geotextilií se prokázala schopnost zadržet a adsorbovat ropné látky. Př́i testování některých typů konstrukce se objevily olejové skvrny v odkapávací nádobě, ale tyto úkapy byly sotva okem detekovatelné, tudíž nebylo možné objem vyteklého oleje kvantifikovat.

Tab. 3 Vyhodnocení adsorbce olejových úkapů [6].

\begin{tabular}{|c|c|c|c|c|c|}
\hline Konstrukce & $\begin{array}{c}\text { Množství } \\
\text { nadávkovan } \\
\text { ého oleje } \\
\text { [ml] }\end{array}$ & $\begin{array}{c}\text { Návrhový } \\
\text { průtok } \\
\text { umělého } \\
\text { deště [l/hod] }\end{array}$ & $\begin{array}{c}\text { Doba } \\
\text { zkrápění } \\
\text { vodou [hod] }\end{array}$ & $\begin{array}{c}\text { Množství } \\
\text { proteklé } \\
\text { vody [l] }\end{array}$ & $\begin{array}{c}\text { Množství } \\
\text { vyteklého } \\
\text { oleje do } \\
\text { odkapávací } \\
\text { nádoby [ml] }\end{array}$ \\
\hline Konstrukce B & 20 & 4,7 & 12,0 & 56,4 & 0 \\
\hline Konstrukce C & 105 & 4,7 & 66,3 & 311,7 & $<1$ \\
\hline $\begin{array}{c}\text { Konstrukce A s geotextilií } \\
\text { TenCate GeoClean }\end{array}$ & 100 & 4,7 & 66,0 & 310,2 & 0 \\
\hline $\begin{array}{c}\text { Konstrukce A s netkanou } \\
\text { geotextilií }\end{array}$ & 100 & 4,7 & 66,0 & 310,2 & $<1$ \\
\hline $\begin{array}{c}\text { Konstrukce B s netkanou } \\
\text { geotextilií }\end{array}$ & 100 & 3,6 & 90,0 & 324,0 & 0 \\
\hline $\begin{array}{c}\text { Konstrukce B s jemnou } \\
\text { perlinkou }\end{array}$ & 100 & 3,6 & 90,0 & 324,0 & $<1$ \\
\hline
\end{tabular}

\section{ZÁVĚR}

Experimentální parkoviště je vybudováno s cílem dlouhodobého provozu a sledování řady parametrů s ohledem na únosnost konstrukčních vrstev, sledování znečištění ropnými produkty a vsakování deštových srážek. Z provedených kontrolních statických zatěžovacích zkoušek únosnosti vyplývá, že př́měs typu biochar nebo určité množství jílovité složky neovlivní zhutnitelnost a únosnost podkladní vrstvy, což bylo ověřeno 
kontrolní statickou zatěžovací zkouškou pro ověření únosnosti zhutněné štěrkodrtě ve třech variantách. V rámci první etapy proběhlo v laboratorních podmínkách, dle jednoduché metodiky, testování simulace znečištění zeleného parkoviště ropnými produkty. Po provedení simulace umělého deště s nadávkováním až $100 \mathrm{ml}$ vybraného oleje lze konstatovat, že ve většině sledovaných modulů bud' nebylo prokázáno protečení oleje konstrukčním souvrstvím, nebo byl prokázán naprosto minimální úkap, který nebylo možno kvantifikovat. V další etapě testování proběhne ověření adsorbčních schopností uvedených geotextilií na olejové úkapy a také vsakovací schopnosti konstrukčních vrstev na venkovním experimentálním parkovišti.

Do budoucna bude vhodné, $\mathrm{v}$ př́ípadě používání tohoto systému odvádění vody z povrchu komunikace, upravit používané směsi, jak z hlediska propustnosti, tak i únosnosti. Za tímto účelem je vhodné neomezovat se jen na používané štěrkodrtě, ale zabývat se i použitím mezerovitých nestmelených směsí a směsí s hydraulickým pojivem. V rámci experimentálního polygonu zeleného parkoviště vybudovaného $\mathrm{v}$ centru AdMaS bylo touto formou uloženo do půdy cca $20 \mathrm{~kg}$ biocharu, což představuje ekvivalent odstranění cca $50 \mathrm{~kg} \mathrm{CO}_{2}$ [6].

\section{Poděkování}

Tento článek byl vytvořen s finanční podporou v rámci řešení standardního specifického projektu FAST-S-217424 „Řešení aktuálních problémů vodního hospodářství měst a obcí“ a s finanční podporou MPO v rámci řešení projektu „Provedení zkoušek biocharu pro jeho inovativní využití jako substrátu zelených parkovišt'“, registrační č. CZ.01.1.02/0.0/0.0/18_215/0021573.

\section{Použité zdroje}

[1] VÍTEK, Jiří. Odvodňování urbanizovaných území podle prinicpů udržitelného rozvoje. Urbanismus a územní rozvoj [online]. 2008, (4) [cit. 2019-09-12]. Dostupné z: http://www.jvprojektvh.cz/photo/sekce/file/2008-06-09_JVPVH.pdf

[2] Pokyny týkající se osvědčených postupů pro omezení zakrývání půdy, zmírnění jeho důsledků a jeho kompenzaci [online]. Lucemburk: Úřad pro publikace Evropské unie, 2012 [cit. 2019-12-07]. ISBN 978-92-79-26206-7. Dostupné z: https://ec.europa.eu/environment/soil/pdf/guidelines/pub/soil_cs.pdf

[3] Zastavování území. EAGRI [online]. Ministerstvo zemědělství [cit. 2019-12-07]. Dostupné z: http://eagri.cz/public/web/mze/puda/ochrana-pudy-a-krajiny/degradace-pud/zastavovani-uzemi/

[4] Guidelines on best practice to limit, mitigate or compensate soil sealing [online]. Luxembourg: Publications Office of the European Union, 2012 [cit. 2021-12-14]. ISBN 978-92-79-26210-4. Dostupné z: https://ec.europa.eu/environment/soil/pdf/guidelines/pub/soil_en.pdf

[5] Zasakovací rošty pro zpevněné propustné povrchy AS-TTE ROŠT. Asio [online]. c2011-2019 [cit. 201909-27]. Dostupné z: https://www.asio.cz/cz/zasakovaci-rosty-pro-zpevnene-povrchy-as-tte-rost

[6] NOVOTNÝ, Michal, Tomáš CHORAZY, Tomáš MACSEK, Jakub RAČEK, Michaela KOCIFAJOVÁ, Ondřej PRAX a Dušan STEHLÍK. Možnosti využití biocharu jako inovativního substrátu pro zelené parkoviště. In: Městské vody 2021. Brno: ARDEC s.r.o., 2021, s. 195-203. ISBN 978-80-86020-92-1.

[7] NABIUL AFROOZ, A.R.M. a Alexandria BOEHM. Effects of submerged zone, media aging, and antecedent dry period on the performance of biochar-amended biofilters in removing fecal indicators and nutrients from natural stormwater. Ecological Engineering [online]. 2017, 102, 320-330 [cit. 2021-06-11]. ISSN 09258574. Dostupné z: doi:10.1016/j.ecoleng.2017.02.053

[8] BORAH, Archita, Marie TAPONAT a Ghazaleh HAGHIGHAT. Review of the Emerging Use of Activated Carbon or Biochar Media as Stormwater Source Controls [online]. [cit. 2021-06-11].

[9] Stockholm Biochar Project. Nordregio [online]. [cit. 2021-12-14]. Dostupné z: https://nordregio.org/sustainable_cities/stockholm-biochar-project/

[10] ŠEVČÍK, Jan. Př́iprava čistírenských kalů pro proces pyrolýzy [online]. Brno, 2019 [cit. 2021-06-08]. Dizertační práce. Vysoké učení technické v Brně, Fakulta stavební. Vedoucí práce Prof. Ing. Petr Hlavínek, CSc., MBA.

[11] HARTIG, Karel. Problematika kalového hospodářství - termická destrukce kalů. Vodní hospodářství. 2017(5). 